\title{
AKTualne WYZWANia DEMOKRACJI I PRAWORZĄDNości w Europie II Europejskie Forum Praw CZŁowieka i Prawa Humanitarnego LUBLIN, 4 KWIETNIA 2019 R.
}

Dnia 4 kwietnia 2019 r. na Katolickim Uniwersytecie Lubelskim Jana Pawła II odbyło się II Europejskie Forum Praw Człowieka i Prawa Humanitarnego zatytułowane: Aktualne wyzwania demokracji i praworząności w Europie (II European Forum on Human Rights and Humanitarian Law, Current Challenges of Democracy and Rule of Law in Europe), którego organizatorem była Katedra Praw Człowieka. Wydarzenie miało rangę międzynarodowej konferencji naukowej.

Demokracja stanowi fundament kultury politycznej kontynentu europejskiego. Jej wspieranie jest jednym z kluczowych postulatów Powszechnej Deklaracji Praw Człowieka (1948 r.), która głosi: „Wola ludu jest podstawą władzy rządu" ${ }^{11}$. Mimo iż demokracja jest uważana za najdoskonalszy system polityczny (spośród istniejących), nie jest pozbawiona pewnych problemów, które w dalszej perspektywie mogą doprowadzić do jej marginalizacji i naruszeń w obszarze praw człowieka, Zasadniczym celem organizatorów podczas II Forum było zatem zidentyfikowanie kluczowych problemów w kontekście demokracji i praworządności w Europie oraz sformułowanie postulatów de lege ferenda w tym zakresie.

Otwarcia konferencji, odbywającej się w Auli Kardynała Stefana Wyszyńskiego w Gmachu Głównym KUL, dokonał przewodniczący Komitetu Naukowego Forum, ks. dr hab. Krzysztof Orzeszyna, prof. KUL, który przywitał prelegentów oraz licznie zgromadzone audytorium: studentów, doktorantów, pracowników naukowych Wydziału Prawa, Prawa Kanonicznego i Administracji KUL oraz gości zagranicznych. Zwrócił on także uwagę na doniosłość problematyki podejmowanej podczas konferencji przywołując najważniejsze myśli św. Jana Pawła II.

Pierwszy referat pt. Zasada podziatu władzy w orzecznictwie Europejskiego Trybunału Praw Człowieka wygłosiła dr Aikaterini Tsampi (Uniwersytet w Groningen). Przytaczając w nim wybrane, najważniejsze orzecznictwo ETPCz,

1 A. Przyborowska-Klimczak, Prawo międzynarodowe publiczne. Wybór dokumentów, Lublin 2008, s. 137. 
prelegentka zwróciła uwagę na to jak ważną rolę odgrywa podział władzy w ustroju demokratycznym. Stwierdziła, że bez jej prawidłowego zapewnienia, nie jest możliwa realizacja efektywnej ochrony indywidualnych praw i wolności. Podkreśliła ponadto, iż zasada ta ma znaczenie w kontekście całego państwa, ale ważna jest także dla poszczególnych, indywidualnych podmiotów.

Drugi referat wygłoszony przez prof. dr hab. Olgę Sadovską (Odeski Uniwersytet Narodowy im. Ilji Miecznikowa) pt. Ukraina - państwo prawa czy bezprawia? dotyczył aktualnej sytuacji ustrojowo-politycznej na Ukrainie. W swojej wypowiedzi prof. O. Sadovska zwróciła uwagę na niewydolność oraz ułomność ukraińskich organów publicznych, co w konsekwencji prowadzi do licznych naruszeń w obszarze poszanowania praw człowieka.

Trzeci referat pt. Zasada demokratycznego państwa prawa zaprezentował ks. dr hab. K. Orzeszyna, prof. KUL. Przybliżył w nim znaczenie wskazanej zasady bazując na regulacjach zawartych w Konstytucji Rzeczypospolitej Polskiej z dnia 2 kwietnia 1997 r. oraz na orzecznictwie Trybunału Konstytucyjnego. Szczególny nacisk położył na materialne treści wynikające z zasady demokratycznego państwa prawnego.

Czwarty referat pt. Praworząność w Polsce. Odpowiedzialność i rzeczywistość przedstawił dr Robert Tabaszewski (KUL), zwracając uwagę słuchaczy na istniejący konflikt pomiędzy polskim rządem a instytucjami Unii Europejskiej w kontekście postanowienia TSUE z dnia 19 października 2018 r. odnoszącego się do ustawy o Sądzie Najwyższym.

Ostatni referat zatytułowany: Wolność przekazywania informacji jako fundament demokracji i praworządności w Europie wygłosił dr Michał Skwarzyński (KUL), który podkreślił znaczenia prawa do informacji. Prelegent jednoznacznie wskazał, że utrudnianie lub całkowite blokowanie wymiany informacji wyłącza możliwość efektywnego funkcjonowania ustroju demokratycznego.

Następnie przewodniczący Komitetu Naukowego Konferencji ks. dr hab. K. Orzeszyna, prof. KUL, otworzył panel dyskusyjny - podczas którego zwłaszcza wystąpienie dr A. Tsampi dało asumpt do ożywionej debaty - a po jego zakończeniu dokonał syntetycznego podsumowania wszystkich wystąpień oraz najważniejszych głosów z dyskusji. Podziękował także prelegentom oraz wszystkim zgromadzonym za udział w wydarzeniu.

Niewątpliwy sukces II Europejskiego Forum Praw Człowieka i Prawa Humanitarnego skłonił organizatorów do bezzwłocznego rozpoczęcia prac nad organizacją III edycji.

Mateusz Hypiak*

Mgr, Katolicki Uniwersytet Lubelski Jana Pawła II; e-mail: mateusz.hypiak@kul.pl, ORCID ID: https:/ / orcid.org/0000-0003-3839-5899. 